\title{
FLOCCULATION TESTS IN RHEUMATOID ARTHRITIS
}

\author{
BY \\ THOMAS N. FRASER \\ From The Gardiner Institute of Medicine, University of Glasgow
}

In addition to specific liver function tests, such as the synthesis of hippuric acid, laevulose tolerance and excretion of dyes, empirical tests have been devised which all depend mainly on excess of gammaglobulin in the serum (Gray, 1942; Kabat and others, 1943). The original object of these tests was threefold: (1) to distinguish between jaundice due to hepatitis and that due to obstruction of the bileducts; (2) to assist in the diagnosis of hepatitis in the early pre-icteric stage; and (3) to follow the course of hepatitis and aid in its prognosis. Two of these empirical tests-serum colloidal gold and cephalin-cholesterol flocculation-have been found to be particularly sensitive in parenchymatous disease of the liver.

According to Gray (1942), the foundation for the diagnostic use of the colloidal gold reaction was laid by Zsigmondy (1901), who observed that certain colloids, especially proteins, prevented the precipitation of colloidal gold suspensions by electrolytes. Lange (1912) found, however, that proteins within certain dilutions did not prevent but actually caused precipitation. Sweet and others (1941) pointed out that when a colloidal gold suspension is added to certain dilutions of blood serum from patients with liver disease flocculation of the colloidal gold occurs in one or more of the first serial dilutions. Gray (1942) performed a series of electrophoretic studies on the serum proteins in all types of liver disease, which revealed that the most characteristic and consistent alteration of the serum proteins was an increase in the gamma-globulin associated with a decrease in albumin. He then studied the effect on the colloidal gold solution of the addition of purified protein fractions to normal serum and obtained the following results:

(a) the addition of pure gamma-globulin to normal blood serum gave a positive colloidal gold reaction;

(b) the purified fractions with alpha- and betaglobulin had no effect;

(c) the albumin fraction inhibited the serum colloidal gold reaction.
As the result of these findings Gray suggested that the mechanism of the serum colloidal gold reaction in liver disease depended upon a relative increase in the gamma-globulin of the blood.

According to Maclagan (1944), Gray's original description of the serum colloidal gold reaction presented certain difficulties, including standardization of the solution. Moreover, while the test gave positive results in 100 per cent. of cases of cirrhosis of the liver, it was also positive in 10 per cent. of normal subjects. To overcome these difficulties, Maclagan devised a modification of Gray's test; this was simpler to perform, requiring only one tube instead of ten. The sensitivity of the reaction in cirrhosis of the liver and hepatitis was unimpaired, and normal subjects gave uniformly negative results.

While the principal use of the serum colloidal gold reaction was in diseases of the liver, it was soon found that positive results were obtained in certain non-hepatic diseases such as malaria, glandular fever, subacute bacterial endocarditis, and rheumatoid arthritis. Carter and Maclagan (1946) found that the test was positive in 76 per cent. of a series of thirty-four patients with rheumatoid arthritis, the results varying from mild to strongly positive.

The cephalin-cholesterol flocculation reaction was first introduced by Hanger (1939) as a test of hepatic efficiency, and was shown by several American workers (Hanger, 1939; Pohle and Stewart, 1941; and Mateer and others, 1942) to be extremely sensitive in the early detection of liver insufficiency. Like the serum colloidal gold reaction it, too, gives positive results with non-hepatic diseases including rheumatoid arthritis. The percentage of positive reactions in the latter disease, however, has been small. Dick (1945) obtained complete flocculation in only two out of forty-one patients with rheumatoid arthritis, the remaining thirty-nine failing to show any flocculation. Maizels (1946) noted a weakly positive result in one out of five cases of rheumatoid arthritis.

The present investigation was undertaken in 
order to determine whether either of the flocculation tests, more particularly the serum colloidal gold reaction, might be of value, not as a diagnostic test as in liver diseases, but as an indicator of the activity or a guide in the prognosis of rheumatoid arthritis. Although the work of Carter and Maclagan (1946) gave promising results, it was felt that a larger series of cases was necessary before any definite opinion could be formed about the value of the serum colloidal gold reaction. In addition, an opportunity was afforded for comparing the results of the flocculation tests with the plasma proteins, erythrocyte sedimentation rate, and other clinical findings.

Maclagan's modification of Gray's serum colloidal gold test and Hanger's cephalincholesterol flocculation test were used throughout the investigation.

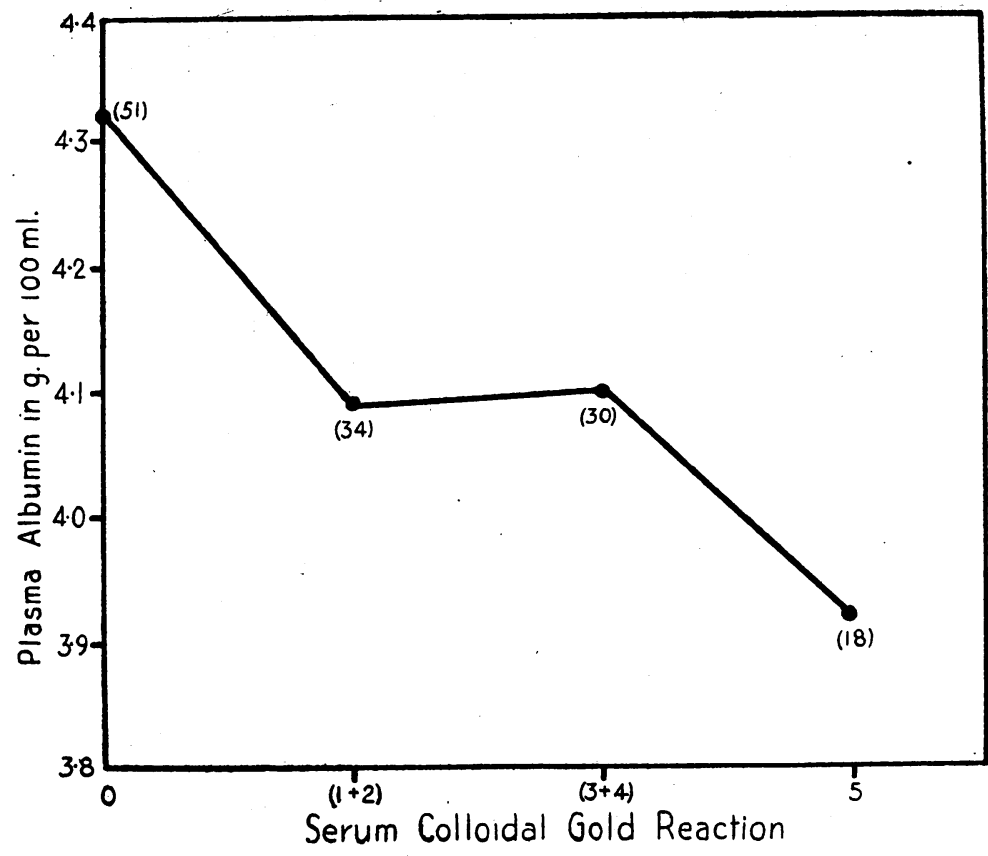

Fig. 1.-Serum colloidal gold reaction and plasma albumin (number of observations shown in brackets).

Table 2 shows the degree of flocculation present

\section{Results}

Normal Controls.-The serum colloidal gold and cephalin-cholesterol flocculation tests were performed on one hundred healthy blood donors with uniformly negative results.

Rheumatoid Arthritis.-One hundred and thirtythree observations with the serum colloidal gold and cephalin-cholesterol flocculation tests were made on a hundred patients suffering from rheumatoid arthritis. Sixty-one per cent. of the former and 19 per cent. of the latter were found to be positive (Table 1). In addition, it was found that in 17 per cent. both tests were positive.

\section{TABLE 1}

SERUM COLLOIDAL GOLD AND CEPHALINCHOLESTEROL FLOCCULATION TESTS IN RHEUMATOID ARTHRITIS

(133 Observations on 100 Cases)

\begin{tabular}{|c|c|c|c|c|}
\hline & & \multirow{2}{*}{$\begin{array}{c}\text { No. of } \\
\text { observations }\end{array}$} & \multicolumn{2}{|c|}{ Positive } \\
\hline & & & No. & $\%$ \\
\hline $\begin{array}{l}\text { Colloidal gold ... } \\
\text { Cephalin-cholesterol } \\
\text { Both tests }\end{array}$ & $\begin{array}{l}\cdots \\
\cdots \\
\cdots\end{array}$ & $\begin{array}{l}133 \\
133 \\
133\end{array}$ & $\begin{array}{l}81 \\
25 \\
22\end{array}$ & $\begin{array}{l}61 \\
19 \\
17\end{array}$ \\
\hline
\end{tabular}

in both tests. It will be seen that complete flocculation was obtained in 18 instances in the case of the serum colloidal gold reaction and in only 5 in the cephalin-cholesterol flocculation test.

TABLE 2

DEGREE OF FLOCCULATION OF SERUM COLLOIDAL GOLD AND CEPHALINCHOLESTEROL TESTS IN RHEUMATOID ARTHRITIS

(133 Observations on 100 Cases)

\begin{tabular}{c|r|r|r|r|r|r|r}
\hline & \multicolumn{6}{|c}{ Colloidal gold } \\
$\begin{array}{c}\text { Cephalin- } \\
\text { cholesterol }\end{array}$ & \multicolumn{6}{|c}{} \\
\cline { 2 - 6 } & 0 & $1+$ & $2+$ & $3+$ & $4+$ & $5+$ & Totals \\
\hline 0 & 49 & 16 & 9 & 8 & 16 & 10 & 108 \\
+ & 1 & 2 & 1 & 1 & 1 & 2 & 8 \\
++ & 0 & 1 & 0 & 1 & 0 & 2 & 4 \\
+++ & 1 & 3 & 0 & 0 & 2 & 2 & 8 \\
++++ & 1 & 1 & 0 & 0 & 1 & 2 & 5 \\
\hline Totals & 52 & 23 & 10 & 10 & 20 & 18 & 133 \\
\hline
\end{tabular}

An attempt was made to see if the flocculation tests showed any correlation with various factors.

Plasma proteins.-The results of the two flocculation tests were compared with the total plasma 


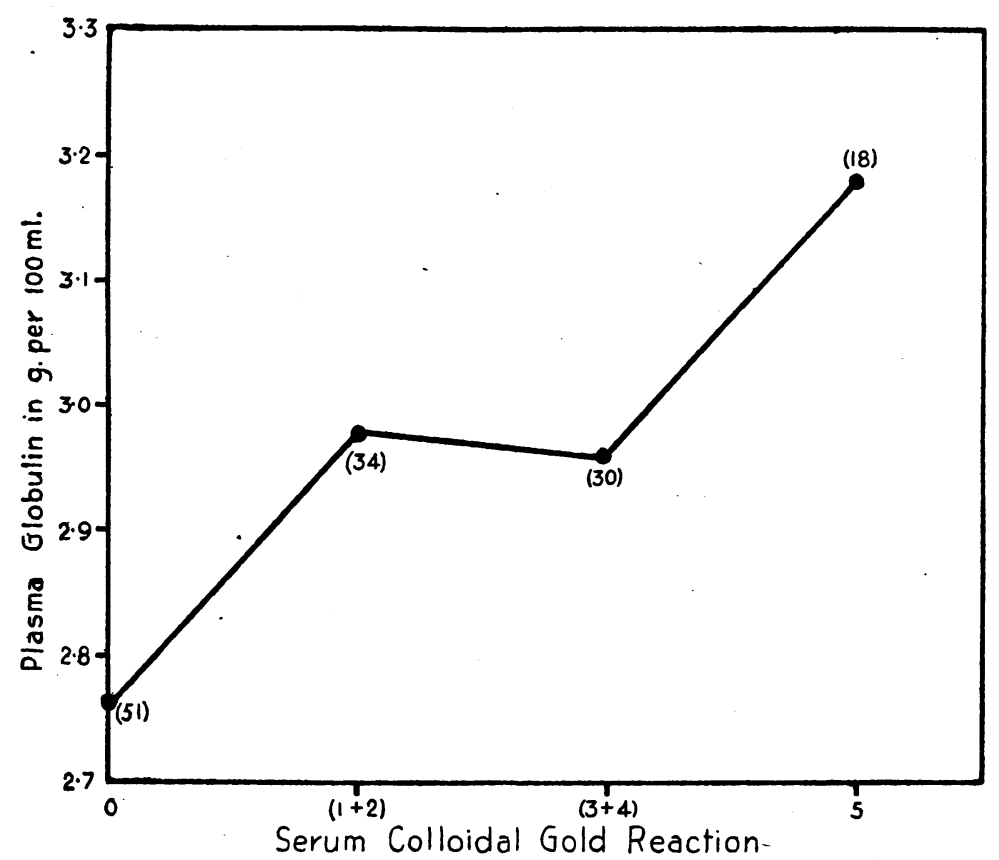

FIG. 2.-Serum colloidal gold reaction and plasma globulin (number of observations shown in brackets).
Other Forms of Rheumatism. -As an additional control series it was considered advisable to perform the serum colloidal gold and cephalincholesterol flocculation tests on patients with other forms of rheumatism. Observations were made on thirty patients with osteo-arthritis, twenty with rheumatic fever, twenty with fibrositis, and two with ankylosing spondylitis. The results are shown in Table 3.

It will be seen from the Table that in osteo-arthritis and fibrositis the results of both tests were uniformly negative. One of the two patients with ankylosing spondylitis gave a mildly positive reaction $(1+)$ with the serum colloidal gold test, while the cephalin-cholesterol flocculation test was negative in both. In rheumatic fever, eight (40 per cent.) of the twenty patients

TABLE 3

the results of the serum colloidal gold reaction did not show any apparent relation to the total protein and fibrinogen, there was a moderate degree of relationship with the albumin and globulin fractions, inverse in the former and direct in the latter (Figs. 1 and 2). The method of charting the results was as follows: the serum colloidal gold values were arranged and recorded in four groups only-viz., $0,1+$ and $2+, 3+$ and $4+, 5+,-$ for this reason; while the results of the serum colloidal gold reaction are generally recorded in one of six groups, $\mathbf{0 , 1 +}$ $2+, 3+, 4+$, and $5+$, considerable difficulty arose in many cases in distinguishing between a $1+$ and a $2+$ reading, and between a $3+$ and a $4+$, as the difference in the amount of flocculation between these figures is small. The corresponding values of the protein fractions in the four groups were averaged.

The results of the cephalin-cholesterol flocculation test did not show any relationship to the plasma proteins.

Other factors.-An attempt was made to correlate the results of the serum colloidal gold and cephalincholesterol flocculation tests with various clinical findings. No relationship was found between either of the tests and the age, sex, duration and degree of arthritis, weight, temperature, white cell count, haemoglobin, focal sepsis, or previous gold therapy.
SERUM COLLOIDAL GOLD AND CEPHALINCHOLESTEROL FLOCCULATION TESTS IN OTHER FORMS OF RHEUMATISM

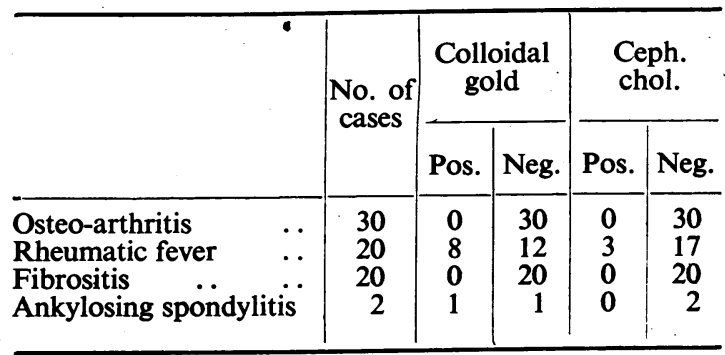

had positive reactions with the serum colloidal gold test, and three (15 per cent.) with the cephalincholesterol flocculation test. The results are shown in greater detail in Table 4.

Effect of Gold Therapy.-The serum colloidal gold and cephalin-cholesterol flocculation tests were performed on thirty patients with rheumatoid arthritis before and after receiving one course of myocrisin injections (total $=1 \mathrm{~g}$.).

Clinically, twenty-five of the thirty patients responded favourably to the gold therapy, the remainder showing no change in their condition. While the results of the serum colloidal gold reaction 
TABLE 4

SERUM COLLOIDAL GOLD AND CEPHALINCHOLESTEROL FLOCCULATION TESTS IN RHEUMATIC FEVER

\begin{tabular}{|c|c|c|c|c|c|c|c|}
\hline \multirow{2}{*}{$\begin{array}{l}\text { Cephalin- } \\
\text { cholesterol }\end{array}$} & \multicolumn{6}{|c|}{ Colloidal gold } & \multirow{2}{*}{ Totals } \\
\hline & 0 & $1+$ & $2+$ & $3+$ & $4+$ & $5+$ & \\
\hline $\begin{array}{l}0 \\
+ \\
++ \\
+++ \\
++++\end{array}$ & $\begin{array}{r}12 \\
0 \\
0 \\
0 \\
0\end{array}$ & $\begin{array}{l}0 \\
0 \\
0 \\
0 \\
0\end{array}$ & $\begin{array}{l}1 \\
0 \\
1 \\
0 \\
0\end{array}$ & $\begin{array}{l}2 \\
0 \\
0 \\
0 \\
1\end{array}$ & $\begin{array}{l}2 \\
0 \\
0 \\
1 \\
0\end{array}$ & $\begin{array}{l}0 \\
0 \\
0 \\
0 \\
0\end{array}$ & $\begin{array}{r}17 \\
0 \\
1 \\
1 \\
1\end{array}$ \\
\hline Totals . & 12 & 0 & 2 & 3 & 3 & 0 & 20 \\
\hline
\end{tabular}

TABLE 5

CEPHALIN - CHOLESTEROL FLOCCULATION TEST BEFORE AND AFTER GOLD THERAPY IN THIRTY CASES OF RHEUMATOID ARTHRITIS

\begin{tabular}{l|c|c|c|c|c|c|c}
\hline & \multicolumn{3}{|c|}{ Cephalin-cholesterol } & \\
\cline { 2 - 6 } & 0 & + & ++ & +++ & ++++ & Totals \\
\hline $\begin{array}{l}\text { No. of } \\
\text { cases }\end{array}$ & Before & 19 & 2 & 2 & 4 & 3 & 30 \\
\hline
\end{tabular}

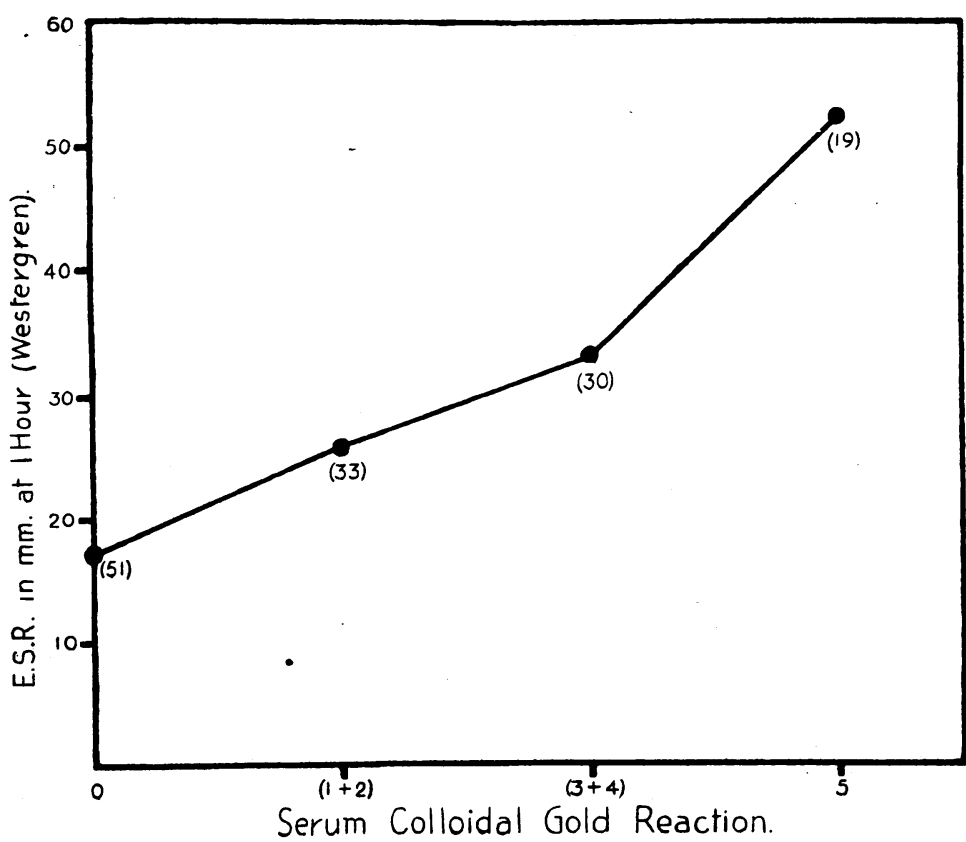

FIG. 3.-Serum colloidal gold reaction and erythrocyte sedimentation rate (number of observations shown in brackets). as a whole showed a change towards normal following therapy, the amount of improvement shown by the test, however, was only partially related to the degree of clinical improvement.

Eleven of the thirty patients who received gold therapy had a positive cephalin-cholesterol flocculation test before treatment. It is of interest to note that in ten of the eleven cases the test was negative at the end of therapy (Table 5).

It was found that there was only a partial relationship between the change in the results of the cephalincholesterol flocculation test and the degree of clinical improvement following on gold therapy.

Relation to Erythrocyte Sedimentation Rate.It was considered of interest to see whether the results of the serum colloidal gold test were related to the changes in the erythrocyte sedimentation rate in rheumatoid arthritis. The results have been recorded graphically in Fig. 3. As before, the colloidal gold values have been arranged into four groups as follows: $0,1+$ and $2+, 3+$ and $4+, 5+$. The corresponding erythrocyte sedimentation rate values in these groups have been averaged. There would appear to be a moderate degree of relationship between the results of the serum colloidal gold reaction and the erythrocyte sedimentation rate.

As the cephalin-cholesterol flocculation test was positive in only 19 per cent. of the estimations the findings have not been recorded graphically, as it was felt that to do so would give an erroneous picture.

\section{Discussion}

Although the flocculation tests are now being employed as a routine in many hospitals, there is still no satisfactory explanation of their mechanism. While in hepatic disease there is some relation between the positive results and the degree of destruction of liver tissue, there is no evidence to suggest that the high percentage of positive findings with the serum colloidal gold test in rheumatoid arthritis is in any way related to liver damage. Baggenstoss and Rosenberg (1943) studied at necropsy the pathological changes in the viscera in thirty patients with rheumatoid arthritis and failed to observe any characteristic hepatic lesion which could be ascribed to 
the disease. It is possible, as Enders (1944) has shown in other diseases, that an antibody attached to the serum gamma-globulin fraction may account for the flocculating power of the blood of patients with rheumatoid arthritis.

In the present investigation an attempt was made to see whether the results of the serum colloidal gold reaction were in any way related to alterations in the plasma proteins. It was found that, whereas there was no apparent relation to the total protein and fibrinogen, there was a moderate degree of relationship with the albumin and globulin fractions, inverse in the former and direct in the latter. It may be, therefore, that a positive serum colloidal gold reaction in rheumatoid arthritis depends on both a quantitative, as well as a qualitative, change in certain of the plasma protein fractions.

It has been shown that in patients who responded favourably to gold therapy the degree of clinical improvement was not accurately reflected by the results of the serum colloidal gold test. For instance, those patients who had shown the greatest clinical improvement would have been expected to have had negative or only mildly positive serum colloidal gold reactions, but this was not invariably the case. This may, of course, be due to the fact that the test takes longer to return to normal than clinical recovery.

A comparison between the results of the serum colloidal gold reaction and the erythrocyte sedimentation rate in rheumatoid arthritis showed that there was a definite relationship between the two tests-for example, there were thirty observations with normal sedimentation rates (up to $10 \mathrm{~mm}$.), the corresponding serum colloidal gold test being negative in all but seven instances, and in these only a mild positive reaction was obtained $(1+)$.

The serum colloidal gold test is thus of value in rheumatoid arthritis, although, as with the erythrocyte sedimentation rate, too much reliance should not be placed on it. As an indicator of the activity and as a guide to the progress of the disease it is probably a less sensitive test than the latter. It is useful, too, in the differential diagnosis between rheumatoid arthritis on the one hand and osteoarthritis and fibrositis on the other. Unfortunately, it is not of any value in the differentiation of rheumatoid arthritis from rheumatic fever, as the test is also positive in an appreciable number of cases of the latter disease. It may be that some factor common to both rheumatoid arthritis and rheumatic fever is responsible for this finding.

There is little to commend the use of the cephalincholesterol flocculation test in rheumatoid arthritis, as it was positive in only one-fifth of the observations.

\section{Summary}

1. The serum colloidal gold test was positive in 61 per cent. of the observations in rheumatoid arthritis and in 40 per cent. of the cases of rheumatic fever. In osteo-arthritis, fibrositis, and normal controls the results were uniformly negative.

2. The cephalin-cholesterol flocculation test gave a positive reaction in 19 per cent. of the observations in rheumatoid arthritis and in 15 per cent. of the cases of rheumatic fever. Negative results were obtained in all the cases of osteo-arthritis, fibrositis; and ankylosing spondylitis, and in all the normal controls.

3. There was a moderate degree of relationship between the results of the serum colloidal gold reaction and the plasma albumin and globulin fractions, inverse in the former and direct in the latter. There was no apparent relation to the total protein or fibrinogen fraction.

4. A relationship was observed between the results of the serum colloidal gold test and the erythrocyte sedimentation rate. It is concluded that the former is a useful test in rheumatoid arthritis, although a little less sensitive than the latter.

5. The cephalin-cholesterol flocculation test would appear to be of little value in rheumatoid arthritis.

\section{REFERENCES}

Baggenstoss, A. H., and Rosenberg, E. F. (1943). Arch. Path., 35, 503.

Carter, A. B., and Maclagan, N. F. (1946). Brit. med. J., 2,80

Dick, A.' (1945). Ibid., 1, 182.

Enders, J. F. (1944). J. clin. Invest., 23, 510.

Gray, S. J. (1942). Proc. Soc. exp. Biol., N.Y., 51, 400.

Hanger, F. M. (1939). J. clin. Invest., 18, 261.

Kabat, E. A., Hanger, F. M., Moore, D. H., and Landow, H. (1943). Ibid., 22, 563.

Lange, C. (1912). Berl. klin. Wschr., 49, 897.

Maclagan, N. F. (1944). Brit. J. exp. Path., $25,15$.

Maizels, M. (1946). Lancet, 2, 451.

Mateer, J. G., Baltz, J. I., Marion, D. F., and Hollands, R. A. (1942). Amer. J. digest. Dis., 9, 13.

Pohle, F. J., and Stewart, J. K. (1941). J. clin. Invest., 20, 241.

Sweet, W. H., Gray, S. J., and Allen, J. G. (1941). J. Amer. med. Ass., 117, 1613.

Zsigmondy, R. (1901). Z. anal. Chem., 40, 697 (quoted by Gray, S. J. (1942) ).

\section{Epreuves de Floculation dans l'Arthrite Rhumatismale \\ RÉSUMÉ}

Cette étude a été entreprise dans le but de déterminer si l'une des épreuves de floculation, et particulièrement la réaction à l'or colloïdal, peuvent présenter un intérêt, non pas comme une épreuve diagnostique comme dans les maladies du foie, mais pour fournir une indication 
de l'activité ou servir de guide dans le prognostic de l'arthrite rhumatismale. Les résultats ont été les suivants:

1. L'épreuve à l'or colloïdal a été positive dans 61 pour cent des cas d'arthrite rhumatismale, et dans 40 pour cent des cas de rhumatisme articulaire aigu. Dans l'ostéo-arthrite, dans la cellulite, et chez les sujets normaux, les résultats ont été uniformément négatifs.

2. L'épreuve de floculation céphaline-cholestérol a donné une réaction positive dans 19 pour cent des cas d'arthrite rhumatismale et dans 15 pour cent des cas de rhumatisme articulaire aigu. On a eu des résultats négatifs dans tous les cas d'ostéo-arthrite, de cellulite, de spondylite ankylosante, et chez tous les sujets normaux.
3. Il existe un certain degré de corrélation entre les résultats de la réaction à l'or colloïdal et les fractions albumine et globuline du plasma, inverse pour la première et directe pour la seconde. Il n'y avait pas de relation apparente avec la protéine totale ou la fraction fibrinogène.

4. On a observé une relation entre les résultats de l'épreuve à l'or colloïdal et le taux de sédimentation sanguine. On en a conclu que la première est une épreuve utile dans l'arthrite rhumatismale, mais moins sensible que la seconde.

5. L'épreuve de floculation céphaline-cholestérol semble n'avoir que peu de valeur dans l'arthrite rhumatismale. 